\title{
ADAPTATION AS STAFF STRESS RESISTANCE INCREASING TOOL
}

\author{
O. Chyhrynets
}

National University of Food Technologies

\begin{tabular}{|c|c|}
\hline Key words: & ABSTRACT \\
\hline $\begin{array}{l}\text { Stress resistance } \\
\text { Staff adaptation } \\
\text { Stressors } \\
\text { Conflict situation } \\
\text { Collective }\end{array}$ & $\begin{array}{l}\text { The paper analyzes the types of stress and the factors } \\
\text { that couse them. The classification of the stress factors that } \\
\text { arise in organizations is given and the ones that are charac- } \\
\text { teristic of the management sphere are distinguished. The } \\
\text { expediency of staff adaptation application for the purpose of }\end{array}$ \\
\hline $\begin{array}{l}\quad \text { Article history: } \\
\text { Received } 03.07 .2018 \\
\text { Received in revised form } \\
25.07 .2018 \\
\text { Accepted } 15.08 .2018 \\
\end{array}$ & $\begin{array}{l}\text { collective stress resistance strengthening is substantiated. } \\
\text { Specifically, the types and directions of staff adaptation at } \\
\text { the enterprise are presented. The essence of the directions of } \\
\text { staff adaptation is revealed and the employee-manager's } \\
\text { social-psychological adaptation is reflected in the importan- }\end{array}$ \\
\hline $\begin{array}{l}\text { Corresponding author: } \\
\text { O. Chyhrynets } \\
\text { E-mail: } \\
\text { ellen.delightful@gmail.com }\end{array}$ & $\begin{array}{l}\text { ce of interaction, and the factors that form the basis of } \\
\text { leadership styles are provided. } \\
\text { The reason of stress can be any situation in which a per- } \\
\text { son reacts with strong emotional excitement is generalized. } \\
\text { The stupor of stress sources is considered: load imbalance, } \\
\text { conflict or uncertainty of roles, monotonous work, critical } \\
\text { physical conditions of work, etc. It is noted that the process } \\
\text { of adaptation of personnel should include not only the } \\
\text { requirements for the duties, but also a set of measures aimed } \\
\text { at social and psychological integration of the employee into } \\
\text { the team. This prevents the formation of an unfavorable } \\
\text { climate and conflicts in the team. The essence of primary and } \\
\text { secondary adaptation of personnel is revealed. Among the } \\
\text { areas of adaptation is organizational, professional and socio- } \\
\text { psychological adaptation. The socio-psychological adaptation } \\
\text { is structured into a temporary situational, stable and general } \\
\text { and the essence of each component is considered. }\end{array}$ \\
\hline
\end{tabular}

DOI: $10.24263 / 2225-2924-2018-24-4-8$

\section{АДАПТАЦІЯ ЯК ІНСТРУМЕНТ ПІДВИЩЕННЯ СТРЕСОСТІЙКОСТІ ПЕРСОНАЛУ}

\section{О.А. Чигринець}

Національний університет харчових технологій

У статті проаналізовано види стресів і фактори, щзо їх спонукають. Надано класифікацію факторів стресів, що виникають в організачіях, та 
виокремлено найбільш характерні для сфери управління. Обтрунтовано доиільність застосування адаптації персоналу з метою посилення стресостійкості колективу. Наведено види та напрями адаптаиії персоналу на підприємстві. Розкрито сутність напрямів адаптащії персоналу та відображено значимість взаємодії прачівник-менеджер для сочіально-психологічної адаптації, визначено чинники, які формують основу стилів керівництва.

3'ясовано, щуо причиною виникнення стресу може стати будь-яка ситуачія, на яку людина реагує сильним емочійним збудженням. Розглянуто сутність джерел стресу: невідповідність навантаження, конфлікт або невизначеність ролей, монотонна робота, критичні фізичні умови праці тощзо. Зазначено, що процес адаптаиії персоналу має включати не лише викладення вимог щодо виконуваних обов'язків, а й комплекс заходів, направлених на соціально-психологічну інтеграцію прачівника в колектив, що запобігає формуванню несприятливого клімату та виникненню конфліктних ситуаиій у колективі. Розкрито сутність первинної та вторинної адаптаиї персоналу. Серед напрямів адаптації розглянуто організаційну, професійну та соиіальнопсихологічну адаптацію. Структуровано соціально-психологічну адаптацію на тимчасову ситуативну, стійку ситуативну $i$ загальну та розглянуто сутність кожної зі складових.

Ключові слова: стресостійкість, адаптаиія персоналу, стресори, конфліктна ситуація, колектив.

Постановка проблеми. Опинившись у потенційно конфліктній ситуації, більшість людей застосовують звичні для них способи поведінки, які не завжди ефективні для запобігання та регулювання спірних питань. Якщо в повсякденному житті різного роду конфліктні ситуації можуть бути вирішені без застосування спеціалізованих знань про конфлікти, то в робочій обстановці таке незнання може виявитися фатальним як для кар'єри співробітника, так і для його емоційного стану. У найбільш складних ситуаціях, коли людина не знає, що необхідно зробити для вирішення конфліктної ситуації, доцільним $є$ залучення спеціаліста-конфліктолога.

Більшість керівників, незважаючи на велику кількість знань у сфері управління людськими ресурсами та величезний життєвий досвід, недостатньо добре розуміються в механізмах виникнення конфліктних ситуацій у трудовому колективі та способах їх конструктивного вирішення. Деякі керівники застосовують практику силового придушення конфліктів, навіть не здогадуючись про позитивні зміни, які можуть настати в результаті зіткнення інтересів співробітників, якщо скерувати конфлікт у конструктивний бік. Разом з тим недостатня увага приділяється посиленню стресостійкості колективу, що сприяє ефективному розв'язанню конфлікту.

Пошук оптимальних способів урегулювання конфліктних ситуацій, що виникають у професійній діяльності, вимагає достатньої кількості знань про причини, способи та механізми виникнення суперечностей всередині колективу. Такі знання підвищують ефективність комунікації і допомагають не 
тільки зробити процес праці спокійнішим, але й підвищити психологічну стійкість членів колективу. Наведені вище твердження обгрунтовують актуальність пропонованого дослідження.

Аналіз останніх досліджень і публікацій. Суттєвий внесок у формування і розвиток положень щодо використання різних підходів та інструментів у складі систем менеджменту зробило чимало вітчизняних і зарубіжних науковців, зокрема: П. Друкер, Г. Захарчин, Ю. Іванов, Б. Мільнер, Л. Мізес, I. Ансофф, І. Бланк, А. Воронкова, В. Герасимчук, Л. Грейнер, Ю. Погорєлов, Й. Шумпетер та ін.

Дослідження проблеми професійних стресів та адаптації персоналу знайшло відображення в останніх публікаціях таких науковців, як С.М. Дмитрієва [1], Н.Ю. Подольчак [2], Л.А. Мацко [3], М.Д. Прищак [4], О.В. Чорнобиль [5], А.Л. Бикова [6]. У працях цих науковців розкрито сутність і причини виникнення професійних стресів і засоби їх подолання, види та напрями адаптації персоналу в організаціях. Разом з тим недостатньо дослідженим залишається питання впливу адаптації на стресостійкість персоналу.

Метою статті $\epsilon$ обгрунтування доцільності застосування адаптації персоналу для підвищення стресостійкості колективу.

Викладення основних результатів дослідження. Насамперед необхідно розглянути основні причини і джерела виникнення стресу в професійній діяльності. Професійний стрес - це напружений стан працівника, що виникає у нього при впливі емоційно-негативних й екстремальних факторів, пов'язаних 3 виконуваною професійною діяльністю [1].

Розрізняють такі різновиди професійного стресу: інформаційний, емоційний, комунікативний, стрес помилки, стрес досягнення і стрес конкуренції [1]. Інформаційний стрес виникає у випадках інформаційних перевантажень, коли працівник не справляється із завданням і не встигає прийняти важливе рішення в умовах жорсткого обмеження в часі. Напруженість може посилитися, якщо прийняття рішення супроводжується високим ступенем відповідальності, а також у випадках невизначеності, при нестачі необхідної інформації, занадто частому або несподіваній зміні інформаційних параметрів професійної діяльності.

Виникнення емоційного стресу пов'язане 3 існуванням прямої загрози (почуття провини), в результаті чого руйнуються глибинні установки й цінності працівника, пов'язані з його професією.

Комунікативний стрес виявляється у конфліктній поведінці, порушенні самоконтролю, наслідком чого стає ускладнення взаємодії з колегами.

Стрес помилки та стрес конкуренції мають спільні риси, адже вникають за відсутності реальних обставин — через неконтрольоване підвищення психічної напруги у зв'язку з безпідствними побоюваннями працівника.

Причиною виникнення стресу може стати будь-яка ситуація, на яку людина реагує сильним емоційним збудженням. Отже, основними джерелами стресу є: психологічна травма або кризова ситуація (втрата близьких людей, розставання з коханою людиною); дрібні щоденні негаразди; конфлікти або спілкування з неприємними людьми; перешкоди, які не дають можливості 
досягти поставлених цілей; відчуття постійного тиску; нездійсненні мрії або занадто високі вимоги до себе; шум; монотонна робота; постійне звинувачення, самого себе в тому, що ви чогось не досягли або щось упустили; звинувачення себе у всьому поганому, що сталося, навіть якщо це сталося не 3 вашої вини; напружена праця; фінансові труднощі; сильні позитивні емоції; сварки з людьми, особливо з рідними (до стресу може привести і спостереження збоку сварок у сім'ї) [2].

Стимули, що викликають стан стресу, отримали назву стресорів. Розрізняють фізіологічні та психологічні стресори. До фізіологічних відносяться больові дії, надмірне фізичне навантаження, екстремальні температури (спека, холод), больові стимули тощо. До психологічних стресорів відносять чинники, які діють своїм сигнальним значенням: загрозою, небезпекою, образою, інформаційним перевантаженням тощо. До них можна віднести необхідність прийняття рішення, відповідальність за що-небудь, образу, переживання, конфлікт, сигнали небезпеки тощо [3].

Стресори можуть бути як реально діючими, так і ймовірними. За часом впливу стресори поділяються на періодичні, безперервні (постійні), гострі (короткочасна дія різко наростаючою сили стресових і екстремальних факторів) і хронічні (тривалі) [3]. Якщо об’єктивно діючий на людину емоційний стимул не визнається шкідливим, його не можна вважати стресором.

Факторами, що впливають на виникнення стану стресу, виступають життєві ситуації, події, які можна систематизувати за інтенсивністю негативного впливу і часу, необхідного на адаптацію. Відповідно до цього розрізняють [3]:

- повсякденні складності, неприємності, труднощі (час на адаптацію до них становить від декількох хвилин до декількох годин);

- критичні життєві, травматичні події (час на адаптацію - від декількох тижнів до декількох місяців);

- хронічні стресори (можуть тривати роками).

Залежно від виду стресора і характеру його впливу виділяють різні види стресу, в найбільш загальній класифікації - фізіологічний і психологічний стрес [3]. Фізіологічний стрес - це фізіологічна реакція організму на дію стресорів (факторів, що викликають стрес). Психологічні стреси поділяються на інформаційні та емоційні. Інформаційний стрес виникає в ситуації, коли людина не справляється із завданням, не встигає прийняти правильні рішення в необхідному темпі при високому ступені відповідальності за прийняті рішення. Емоційний стрес з'являється в ситуації загрози, небезпеки, образи тощо. Найбільш руйнівні для організму психологічні стреси.

Стрес може бути викликаний чинниками, пов'язаними з роботою і діяльністю організації або подіями особистого життя людини. Якщо ми звернемо увагу на життєві ситуації і події, здатні викликати стрес, то побачимо, що деякі з них є позитивними і сприятливо впливають на наше життя (весілля, особистий успіх, народження дитини, успішне складання іспитів). Крім того, протягом життя ми відчуваємо й інші позитивні відчуття: наприклад, радість (закінчення школи, інституту, зустріч з друзями і рідними, перемога улюбленої команди), любов, творчий підйом (натхнення), досягнення визначного спортивного результату тощо. 
Однак стресову напругу здатні викликати як позитивні, так і негативні ситуації. Деякі життєві ситуації, що викликають стрес, можна передбачити, наприклад, зміну фаз розвитку та становлення сім'ї або ж біологічно зумовлені зміни в організмі, характерні для кожного з нас. Інші ситуації, несподівані і непередбачувані, особливо раптові (нещасні випадки, природні катаклізми, смерть близької людини), ми передбачити не можемо. Існують також ситуації, зумовлені поведінкою людини, прийняттям будь-яких рішень, певним ходом подій (розлучення, зміна місця роботи або місця проживання тощо). Кожна 3 подібних ситуацій здатна викликати душевний дискомфорт. Тому людині необхідні хороші адаптаційні здібності, які допоможуть пережити найважчі життєві ситуації, вистояти в жорстких життєвих випробуваннях.

Розглянемо фактори, здатні викликати стрес всередині організації [1]:

1. Перевантаження або, навпаки, низьке навантаження. Наприклад, працівнику доручили занадто багато завдань або дали мало часу на їх виконання. У цьому випадку, зазвичай, виникає занепокоєння, фрустрація (почуття катастрофи), а також відчуття безнадійності і матеріальних втрат. Однак недовантаження може викликати точно такі ж почуття. Робітник, який отримує завдання, що не відповідають його можливостям, зазвичай відчуває фрустрацію, занепокоєння щодо своєї цінності в соціальній структурі організації.

2. Конфлікт ролей. Конфлікт ролей виникає, коли до працівника висувають суперечливі вимоги. Наприклад, продавець може отримати завдання негайно реагувати на прохання клієнтів, але коли бачать, що він розмовляє 3 клієнтом, то кажуть, щоб він не забував заповнювати полиці товаром. Конфлікт ролей може також статися в результаті порушення принципу єдиноначальності. Два керівники в ієрархії можуть дати працівникові суперечливі вказівки. Наприклад, директор заводу може зажадати від начальника цеху максимально збільшити випуск продукції, в той час як начальник відділу технічного контролю вимагає дотримання стандартів якості. Конфлікт ролей може також виникнути в результаті відмінностей між нормами неформальної групи і вимогами формальної організації. У цій ситуації індивідуум може відчути напругу і занепокоєння, тому що хоче бути прийнятим групою, 3 одного боку, і дотримуватися вимог керівництва - 3 іншого.

3. Невизначеність ролей. Невизначеність ролей виникає тоді, коли працівник невпевнений у тому, чого від нього чекають. На відміну від конфлікту ролей тут вимоги не будуть суперечливими, але вони нечіткі і невизначені. Люди повинні мати правильне уявлення про очікування керівництва: що і як вони повинні робити і як їх після цього будуть оцінювати.

4. Нецікава робота. Працівники, які мають цікавішу роботу, проявляють менше неспокою і менш схильні до фізичних нездужань, ніж ті, які займаються нецікавою роботою. Однак погляди на поняття «цікава» робота у людей різняться: те, що здається цікавим одному працівнику, зовсім не обов'язково буде цікаво іншому.

5. Інші фактори. Стрес може виникнути через погані фізичні умови: через недотримання температурного режиму приміщення, поганого освітлення або надмірного шуму. Неправильні співвідношення між повноваженнями і відпо- 
відальністю, погані канали обміну інформацією в організації і необгрунтовані вимоги співробітників один до одного теж можуть викликати стрес.

У професійній управлінській діяльності стресові ситуації можуть бути викликані динамічністю подій, необхідністю швидкого прийняття рішення, неузгодженістю між індивідуальними особливостями, ритмом і характером діяльності. Факторами, що сприяють виникненню емоційного стресу в цих ситуаціях, можуть бути недостатність інформації, їі суперечливість, надмірна різноманітність або монотонність, оцінка роботи, як перевищує можливості працівника за обсягом або ступенем складності, суперечливі або невизначені вимоги, критичні обставини чи ризик при прийнятті рішення.

У сучасних наукових працях серед засобів посилення стресостійкості персоналу розглядаються виключно фізіологічні та психологічні вправи (заходи), які допомагають персоналу у подоланні стресу. Зокрема, до них належать застосування технік розслаблення, залучення працівників до прийняття рішень, впровадження систем тайм-менеджменту [4].

Водночас адаптація персоналу розглядається виключно як фактор підвищення ефективності діяльності, як інструмент навчання та розвитку персоналу [5]. Науковці у своїх працях не приділяють належної уваги можливості застосування адаптації персоналу як інструменту підвищення стресостійкості персоналу.

3 метою обгрунтування доцільності застосування адаптації для підвищення стресостійкості персоналу необхідно дослідити ії вплив на здатність працівника до подолання стресів.

Важливими чинниками, які поліпшують адаптацію в професійних групах, $\epsilon$ соціальна згуртованість, здатність будувати міжособистісні відносини, можливість відкритої комунікації.

Залежно від наявності попереднього досвіду роботи у працівника, виділяють два види адаптації [6]:

- первинна, тобто адаптація кадрів без досвіду професійної діяльності;

- вторинна, тобто адаптація працівників, що мають досвід професійної діяльності (наприклад, у разі зміни сфери діяльності або підвищення до керівних посад).

Процес адаптації передбачає такі напрями [6]:

- організаційна адаптація;

- професійна адаптація;

- соціально-психологічна адаптація.

Організаційна адаптація передбачає ознайомлення працівника зі структурою організації та особливостями організаційної культури, засвоєння працівником правил внутрішнього розпорядку. Професійна адаптація проявляється в коригуванні професійних навичок та умінь до необхідного рівня. Соціально-психологічна адаптація спрямована на пристосування працівника до взаємовідносин у колективі, в т. ч. до стилю керівництва.

Професійна адаптація нового працівника, як правило, розпочинається ще до прийому на роботу. В процесі співбесіди потенційний працівник ознайомлюється 3 вимогами до його професійної діяльності, співвідносить 3 ними 
наявні теоретичні знання і досвід, набутий на попередньому місці роботи. Тож співбесіда направлена не тільки на визначення відповідності рівня працівника, але й дозволяє працівнику більшою мірою усвідомити зміст та особливості професійної діяльності, яку він здійснюватиме.

Соціально-психологічна адаптація включає:

- тимчасову ситуативну адаптацію, яка легко може перейти у стан дезадаптації в результаті внутрішньопсихологічних змін (наприклад, актуалізації нових потреб і установок) чи змін деяких аспектів ситуації;

- стійку ситуативну адаптацію - довготривала адаптованість в окремих типових ситуаціях, в яких індивід опиняється доволі часто;

- загальна адаптація - потенціальна здатність адаптуватися в широкому спектрі типових ситуацій, які найчастіше трапляються в певному соціальному оточенні.

Якщо зробити проекцію наданої класифікації на сферу праці, то можна стверджувати, що тимчасова ситуативна адаптація притаманна працівнику на стадії випробувального терміну. Після чого відбувається стійка ситуативна адаптація, яка 3 досвідом змінюється на загальну адаптацію.

Перші робочі дні працівника характеризуються наявністю таких психічних станів: бажання успішно пройти випробувальний термін, прагнення добре себе зарекомендувати, висока активність і позитивні очікування. Разом з тим працівник може відчувати тривожність, невпевненість, страх під час спілкування $з$ колегами тощо. Зазвичай, подібні негативні відчуття $є$ проявом низької самооцінки. Професійний HR має вчасно зафіксувати наявність проявів низької самооцінки у працівника і за необхідності - вчасно надати допомогу для запобігання проявам емоційного вигорання.

Взаємодія з керівником є однією з важливих складових адаптації працівника. Керівник оцінює якість виконання професійних завдань працівником, приймає рішення щодо результатів випробувального терміну або підвищення посади.

Кожний керівник дотримується певних правил управлінської діяльності, які у менеджменті називають «стилем керівництва». Стиль керівництва формується на основі здібностей, рис характеру, темпераменту, методів вирішення конфліктів. Це визначає, як він взаємодіє із колективом та підлеглими, як поводиться в екстрених ситуаціях і які методи використовує в міжособистісних конфліктах.

\section{Висновки}

Враховуючи наведений аналіз, можна зробити висновок про позитивний вплив адаптації на підвищення стресостійкості персоналу. Зокрема, організаційна та соціально-психологічна адаптація сприяють послабленню дії стресорів на працівника, посилюють його здатність до подолання стресових ситуацій.

Нехтуючи важливістю процесу адаптації персоналу і зводячи його лише до викладення вимог щодо виконуваних обов'язків, керівники позбавляють себе можливості запобігання передумовам виникненню конфліктних ситуа- 
цій. Важливим фактором посилення стресостійкості персоналу є його соціально-психологічна адаптація.

Подальші наукові дослідження можуть бути спрямовані на визначення ефективності застосування адаптації для профілактики конфліктів у колективі.

\section{Лiтература}

1. Дмитрісва С.М. Особливості профілактичної роботи по попередженню професійного стресу у майбутніх фахівців з фінансів, економіки та менеджменту туристичної індустрії. Актуальні проблеми, сучасний стан та перспективи розвитку індустрії туризму в Україні та Польщі: Матеріали VII Міжнародної науково-практичної конференції / За ред. Саух І.В. - Житомир : Вид-во ЖФ КІБІТ. — С. 187-192.

2. Подольчак Н.Ю. Сутність, причини виникнення та підходи до регулювання стресових ситуацій на підприємствах / Н.Ю. Подольчак, І.М. Дорош, О.І Дорош // Вісник Національного університету «Львівська політехніка». — 2013. — № 778 : Менеджмент та підприємництво в Україні: етапи становлення і проблеми розвитку. - С. 101-108.

3. Мацко Л.А. Основи психології та педагогіки : Навчальний посібник / Л.А. Мацко, М.Д. Прищак. - Вінниця : ВНТУ, 2009. - 158 с.

4. Заболотна В.О. Соціально-психологічні технології корекції рівня стресу в організаціях / В. О. Заболотна // Актуальні проблеми соціології, психології, педагогіки. — 2015. № 2. - C. 26-34.

5. Чорнобиль О.В. Адаптація персоналу як напрям діяльності систем навчання та розвитку вітчизняних підприємств. Теорія та практика державного управління: зб. наук. пр. Харків : Вид-во ХарРІ НАДУ «Магістр», 2015. — Вип. 1 (48). — С. 196-203.

6. Бикова А.Л. Складові ефективної адаптації персоналу / А.Л. Бикова, Д.Д. Паранько // «Молодий вчений» — 2016 - № 12.1(40) — С. 640-646. 